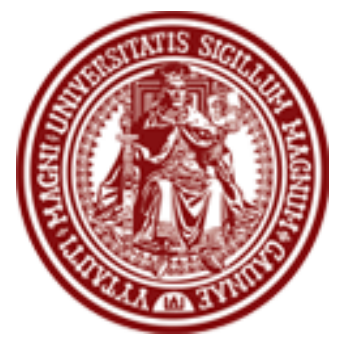

BALTIC JOURNAL OF LAW \& POLITICS

VOLUME 7, NUMBER 1 (2014)

ISSN 2029-0454

http://www.degruyter.com/view/j/bjlp

Cit.: Baltic Journal of Law \& Politics 7:1 (2014): 70-96

DOI: $10.2478 / b j l p-2014-0005$

\title{
THE COMPANY DIRECTOR'S LIABILITY FOR UNTRUE STATEMENTS
}

\section{Leonid Tolstov}

Ph.D. Candidate

University of Tartu, Faculty of Law (Estonia)

Contact information

Address: Roosi 28-2, 51009 Tartu, Estonia

Phone: +372 5049961

E-mail address: Leonid.Tolstov@varul.com

\section{Janno Lahe}

Associated Professor of Civil Law; Dr. iur. University of Tartu, Faculty of Law (Estonia)

\section{Contact information}

Address: Näituse 20, 50409 Tartu, Estonia

Phone: +372 7375992

E-mail address: Janno.Lahe@ut.ee

Received: February 10, 2014; reviews: 2; accepted: May 15, 2014.

\section{ABSTRACT}

In the modern information society the success or failure of a person participating in activities related to legal issues depends increasingly more on the relevance and correctness of available information and this is why higher demands are put on giving out information. In the context of company law it is evident that although the company is always liable for the information issued, in reality it is not the legal person giving out information, but its legal representative (the director) instead. Therefore, it would be reasonable to ask whether the director could simply hide behind the company; or, should the director also be held personally liable for disclosing untrue statements? The aim of this article is, on the basis of English, German, Spanish and Estonian law, to analyze if and in which cases a director can be held personally liable for disclosing false information to a third party in the name of a company and what the optimal standard of a directors' liability for disclosing false 
information could be. The liability of the company itself is not the current article's object of the research.

\section{KEYWORDS}

Director's liability, tort liability, untrue statements, precontractual negotiations, statutory duty 


\section{INTRODUCTION}

In principle, directors ${ }^{1}$ are not liable to companies' obligations. If they have acted in the name of the company then their personal liability to third parties is generally precluded. However, the director's right of representation gives him/her unlimited authority to act on behalf of the company, which may tempt the director to start using that authority for his/her own benefit or in the interests of connected persons. By taking into consideration essential public interests, such as the reliability of economic activities of a company, fairness in distribution and social peace, most legislators have steadily moved towards making the duties and liability of directors stricter. ${ }^{2}$ However, in light of the economic crisis that has been troubling Europe for a few years now, it is reasonable to ask about the sensible boundaries of directors' liability-which criteria of liability would be best in the sense that directors would not be fearful of taking business risks, but at the same time legitimate interests of third parties would be sufficiently protected as well?

An important group of cases where interests of third parties may be damaged through fulfilment of directors' functions is related to giving out false information. Through violation of trust and issuance of false information the director may cause substantial damage to creditors and investors of the company. Causing damage by using untrue statements is especially relevant due to rapid development of information technology where all kind of information plays a more important part in decision-making than ever before.

The article uses a comparative analysis of English, German, Spanish and Estonian law to explore the tortious liability of directors to third parties deriving from disclosure of false information. ${ }^{3}$ From the mentioned countries English law represents the common law legal system; German and Spanish law, however, respectively represent the Germanic and Romanic legal families. Analysis of Estonian law reveals the situation of a former Soviet Union republic in comparison to the above mentioned countries; more specifically, in what way has the issue of

\footnotetext{
${ }^{1}$ To explain the term used: in countries studied in the article the counterparts of a well-known 'director' of the English law are 'Geschäftsführer' in a GmbH or 'Vorstandsmitglied' in an AG in Germany, 'administrador' in Spain and 'juhatuse liige' (the member of the management board) in Estonia. For better readability, the term 'director' is used throughout the article.

${ }^{2}$ Felix Steffek, Gläubigerschutz in der Kapitalgesellschaft [Creditors Protection in a Company] (Tübingen: Mohr Siebeck, 2011), p. 261-262.

${ }^{3}$ For the purpose of this article third parties are primarily company's creditors and persons who have started precontractual negotiations with the company, including persons who have started negotiations in order to acquire company's shares or securities and who might need to file a tortious claim against the director. The nature of a debt relationship between existing shareholders and directors (whether it is tortious, contractual or 'some other' debt relationship) deserves a separate thorough analysis and is, therefore, not analysed in the article.
} 
directors' liability (for disclosure of false information) developed during the 20 years of independence? ${ }^{4}$

With the exception of some special protection provisions there is no specific basis for claims in German, Spanish and Estonian law against the director in the case of false information being disclosed. However, in common law two torts have been developed in connection with untrue statements: liability for deceit (or fraud) and for negligent misrepresentation (or misstatement). The purpose of both bases is to avoid causing damage to creditors, which may be the result of using false information when concluding transactions and determining the conditions of transactions. ${ }^{5}$ As there is no clear basis for claims in German, Spanish and Estonian law when false information is disclosed, it will be ascertained in the article if and through which legal instruments would it be possible to impose a personal liability on directors for untrue statements. As a result of this comparative analysis the main aim of the article is to find criteria that could be optimal from the viewpoint of directors' liability for untrue statements.

Since the research object of the article is liability of directors, other noncontractual liability situations related to disclosure of untrue statements, such as liability of professional advisers and performing agents, are not included in the article.

\section{THE DIRECTOR'S LIABILITY FOR INTENTIONAL DISCLOSURE OF}

\section{FALSE INFORMATION}

An economy can function successfully if parties to economic circulation trust each other. Not all data related to transactions can always be verified and often parties have no other option but to base their decisions on confirmations received from the other party to the transaction. If there was no trust between parties, no transactions would be concluded and economic circulation as a whole would cease to function. The purpose of civil law is to guarantee protection of parties to economic circulation while interfering with people's discretion as little as possible. Therefore, holding offenders liable in situations where they have disclosed false information, but no harm to other parties has been caused is not advisable. Also, it would not be practical for law to interfere with all cases of disclosure of untrue statements, but simply with more 'severe' violations.

\footnotetext{
4 The development of modern Law of Obligations Act (LOA) (State Gazette, (Riigi Teataja), part 1, November 29, 2013, No. 4) took almost 11 years after the Republic of Estonia gained independence and the legislator had enough time to compare different legal systems in Europe and decide which ones to use as bases for Estonian law. Although Dutch, Swiss and Austrian laws have been used as examples as well, main model law for the LOA has been the German BGB (Paul Varul, et al., Võlaõigusseadus I, Kommenteeritud väljaanne [Law of Obligations Act I, Commented Edition] (Tallinn: Juura, 2006), p. 2).

${ }^{5}$ Felix Steffek, supra note 2, p. 566.
} 
Intentional disclosure of false information to another party is the gravest form of disclosure of untrue statements and in all countries studied in the article it can form a basis for holding the offender liable. Intentional deceit may also give ground to rescission of a transaction. ${ }^{6}$ In case of nullity of transaction the plaintiff's claim for damage may lapse if, for example, the transaction is fully reversible. However, nullity of transaction does not rule out filing a claim for damage if damage exists. ${ }^{7}$

If a director has caused damage to a third party by disclosing false information then it is primarily seen as a basis for company's liability to third persons. ${ }^{8}$ Within its internal relationship the company may in turn file a recourse claim. ${ }^{9}$ However, if the company is unable to fulfil the claim for damage, the question arises of whether the third party could file its tortuous claim directly against the director instead?

English law does not permit a director to hide behind the vicarious liability of his company where he is fraudulent. ${ }^{10}$ In Standard Chartered Bank $v$ Pakistan National Shipping Corporation ${ }^{11}$ a director knowingly and deliberately made a false statement in order to receive payment on the basis of a letter of credit. The House of Lords decided that a director should be held personally liable for the deceit. As Lord Hoffman said: "No one can escape liability for his fraud by saying 'I wish to make clear that I am committing this fraud on behalf of someone else and am not to be personally liable".

This is the tort for deceit (or fraud), which enables a creditor to file a claim directly against a director. In order to hold a director liable for deceit, it is important to ascertain that false information was disclosed to the injured party and

\footnotetext{
${ }^{6}$ E.g., in Spanish law the deceived party may rescind the transaction; however, only if the deceit is grave (dolo grave). Art 1270 of Spanish Civil Code (CC), Official State Bulletin [Boletín Oficial del Estado, BOE] BOE-A-1889-4763; The Judgment of the Provincial Court (SAP) Palma de Mallorca 1095/2013 of June 4, 2013. It is also possible to rescind a transaction concluded through deceit in England (e.g., Car and Universal Finance Co Ltd v Caldwell [1965] 1 QB 525), in Germany (art 123 of the German Civil Code [Bürgerliches Gesetzbuch, BGB], Federal Law Gazette [Bundesgesetzblatt, BGB/] I p. 42, 2909, 2003 I p. 738) and in Estonia (art 90 of the General Part of the Civil Code, State Gazette [Riigi Teataja], part 1, December 6, 2010, No. 12).

7 For example, The Spanish Supreme Court stated in its decision of 24 April 2009 that a plaintiff is free to decide whether to file an annulment claim together with the claim for damage, or demand only compensation for damage or only annulment of the transaction. The authors will not handle the issues related to annulment of transactions or extent of claims for damage more thoroughly in the article.

${ }^{8}$ E.g., in German law art 31 of the BGB stipulates the so called principle of organ theory, according to which company is liable for damage caused to third parties by a director (Heinz Georg Bamberger and Herbert Roth, Beck'scher Online-Kommentar BGB, 27 th ed. (München: C.H.Beck, 2013), § 31 at Rn. 1, 3, 5 and 10). There is a similar provision in Estonian law in art 31(5) of the General Part of the Civil Code Act. English courts do not proceed from the organ theory; however, general rules of representation (law of agency) also place liability first of all on the principal (Felix Steffek, supra note 2, p. 259).

${ }^{9}$ If a director is also held liable for the damage caused then, for example, in German law whole liability will fall solely on the director within the internal relationship based on an analogy with art 840(2) of the BGB (Franz Jürgen Säcker and Roland Rixecker, Münchener Kommentar zum Bürgerlichen Gesetzbuch, $6^{\text {th }}$ ed. (München: C.H. Beck, 2012), $\S 31$ at Rn. 45). Possible liability of a director within an internal relationship remains outside the scope of this article.

10 Peter Loose, Michael Griffiths, and David Impey, The Company Director: Powers, Duties and Liabilities, $11^{\text {th }}$ ed. (Jordans, 2011), p. 277.

${ }_{11}$ Standard Chartered Bank v Pakistan National Shipping Corporation, [2002] UKHL 43, [2003] 1 All ER 173.
} 
the director was aware of the incorrectness of information or at least the director had no serious reason to believe that the information was correct. ${ }^{12}$ Deceit in English law presupposes an active misrepresentation and merely remaining silent does not, as a rule, result in the liability of a director. ${ }^{13}$ Therefore, the director may not be held liable on the basis of deceit simply for hiding company's solvency problems from the other party to the transaction. ${ }^{14}$

The intention of the director did not have to be the cause of damage; it is enough if the director's intention was to make the claimant act upon it. ${ }^{15}$ In addition, the claimant must rely on the statement according to the common law. When making business decisions people often base their decisions on information coming from different sources; however, even if the claimant relied on other circumstances as well besides the defendant's misrepresentation, it does not stop the claimant from filing a claim, except if the defendant's fraud was obvious. The claimant must prove that the misrepresentation of the defendant had a real or substantial effect on the claimant's decision. ${ }^{16}$ It should be added that in general a creditor can only demand compensation for negative interest. ${ }^{17}$

In the legal systems of the other countries under consideration here, there is no corresponding specific basis for tortious claim; however, that does not mean that the director is not held liable for deceit in those countries. In German, Spanish and Estonian law directors' deceit cases are solvable through general tortious bases of liability.

In German law a director may be held personally liable for deceiving a creditor if the director intentionally behaves contrary to good morals. ${ }^{18}$ One of the central questions arising from the liability under article 826 of the German Civil Code (BGB) is whether an offender's deed is contrary to good morals and how the offender's

\footnotetext{
${ }^{12}$ W. V. H. Rogers, Winfield \& Jolowicz on Tort, $17^{\text {th }}$ ed. (London: Sweet\&Maxwell, 2006), p. 472 et seq. 13 There are, however, some exceptions: a defendant may be held liable for stating half-truth, in case only partial information was disclosed about some circumstances and the part that was left unsaid would have negated the disclosed information. Also, the defendant may be held liable if he/she disclosed truthful information that became false later on and the defendant did not warn the creditor. In addition, directors' obligation to disclose information may derive from a statute, e.g., Securities Market Regulation (Simon Deakin, Angus Johnston, and Basil Markesinis, Markesinis and Deakin 's Tort Law, $5^{\text {th }}$ ed. (New York: Oxford, 2003), p 502).

${ }^{14}$ Felix Steffek, supra note 2, p. 572. In case of a company's bankruptcy a director may be, however, held personally liable on the basis of the Insolvency Act (IA), 1986, s 214. The basis for compensation obligation in the insolvency is, however, not so much disclosure of untrue statements (or failure to disclose important information), but failure to fulfil other statutory duties (in English law: wrongful trading according to the IA 1986, s 214; in Germany, Estonia and Spain: violation of the duty to file a bankruptcy petition). The issue of directors' bankruptcy liability remains outside the scope of this article. ${ }^{15}$ R. F. V. Heuston and R. A. Buckley, Salmond and Heuston on the Law of Torts, $21^{\text {st }}$ ed. (London: Sweet\&Maxwell, 1996), p. 372-373.

${ }_{16}^{16}$ W. V. H. Rogers, supra note 12 , p. 480 et seq.

17 In some exceptional instances English courts have found that lost profit should be compensated when the plaintiff is able to prove that a particular income stream would have been guaranteed for him/her if the defendant had not committed deceit (Simon Deakin, Angus Johnston, and Basil Markesinis, supra note 13, p. 505).

18 Art 826 of BGB. See Wilhelm Uhlenbruck and Heribert Hirte, Insolvenzordnung, Kommentar [Commantary of the Insolvency Act], $13^{\text {th }}$ ed. (München: Verlag Franz Vahlen, 2010), p. 314.
} 
intent is related to it. Whether a deed is considered contrary to good morals is always at the discretion of courts and is to a great extent dependent on the circumstances of the specific case. Good morals have been defined as arising through persons with a sense of common decency and fairness (in German: 'Anstandsgefühl aller billig und gerecht Denkenden'); however, in judicial practice it is difficult to use that formula in solving a specific case due to its generality. ${ }^{19}$

Intentional behaviour contrary to good morals as a basis for general tortious claims is a significantly wider concept than deceit as it is known in common law, because intentional behaviour contrary to good morals includes any kind of intentional and damaging behaviour that could be recognized as being contrary to good morals by courts. ${ }^{20}$ In a narrower sense being contrary to good morals may mean intentionally disclosing false information that is trusted by the injured party similarly to deceit. Unlike the principal rule valid in English law, liability of directors for intentional withholding of information pursuant to article 826 of the BGB has been recognized in German legal practice. ${ }^{21}$

However, not any kind of exaggeration or glorification of circumstances is considered contrary to good morals in Germany. Decisive factors are expectations of the recipient of information towards the information that had to be known to the person who disclosed it. The act is considered contrary to good morals if unfavorable facts are knowingly covered up in order to make the other party take a risk $\mathrm{s} /$ he would not take if $\mathrm{s} /$ he was aware of the true nature of things. ${ }^{22}$

Intent of a director does not have to be aimed at damaging the injured party; it is only necessary to show that the director was aware of the possibility of causing damage; the director does not have to foresee for certain that damage will be caused, s/he just has to consider causing damage possible (dolus eventualis). ${ }^{23}$ According to German authors, the injured party's contributory fault cannot be a basis for decreasing the liability of the director even if the misdeed has been caused

${ }^{19}$ Kurt Rebmann, Franz Jürgen Säcker, and Roland Rixecker, Münchener Kommentar zum Bürgerlichen Gesetzbuch, Schuldrecht, Besonderer Teil III [Commetary of the Civil Code, Civil Law, Special Part III], Vol. 5, $4^{\text {th }}$ ed. (München: C. H. Beck, 2004), p. 1898.

${ }^{20}$ E.g., in Germany it has been considered possible to hold a director liable based on art 826 of the BGB if the director intentionally causes insolvency of the company, carries out an obviously hopeless reorganisation, intentionally violates the duty to assist in company's bankruptcy proceedings (Lutz Michalski, et al., Kommentar zum Gesetz betreffend die Gesellschaften mit beschränkter Haftung (GmbH-Gesetz) [Commentary of the GmbH Act], Vol. 2 (München: C. H. Beck, 2002), p. 533 et seq.).

21 E.g., deliberate cover-up of company's insolvency (BGH (German Supreme Court's Judgment [Bundesgerichtshof]) NJW-RR 1992, 1061).

22 Maria Cristina Ciota, Die deliktische Aussenhaftung des Vorstandes einer Aktiengesellschaft [Tortious Liability of the Management Board of a Public Limited Company] (Aachen: Shaker Verlag, 2008), p. 186 et seq.

${ }^{23}$ In German judicial practice the notion of intent has been made even wider and persons have been held liable based on art 826 of the BGB for recklessness (in the sense of conscious and gross negligence) as well (Kurt Rebmann, Franz Jürgen Säcker, and Roland Rixecker, supra note 19, p. 1902-1903). 
by the injured party's gross negligence during the verification of presented information. ${ }^{24}$

In Germany, when damage has been caused to a third party by deliberate reporting of false information, the third party is allowed to claim compensation from the director for the negative interest. ${ }^{25}$

In Spain deceit (dolo) takes place when one contracting party induces the other contracting party with malicious acts to conclude a contract which would not have been concluded otherwise. ${ }^{26}$ Deceit presumes deliberate acts from one contracting party in order to subject the other contracting party to its will and create a fraudulent representation of reality in his/her mind. ${ }^{27}$ There must be a cause-and-effect relationship between such actions and the contractual decisions of the other party and those actions must also have determinative importance on the decisions made. ${ }^{28}$ If the misdeed of the other contracting party is caused by his/her own negligence in verifying information which is easily accessible, it may give grounds to discharging the defendant from liability. ${ }^{29}$

If a director acts deceitfully (doloso in Spanish) during contractual negotiations held with a third party or during the fulfilment of the contract and such wrongful acts have directly caused damage to the injured party, the director may be held liable to compensate for the damage caused to the third party according to article 1902 of the Spanish CC and article 241 of the Spanish Companies Act (TRLSC). ${ }^{30}$ Such behavior may be expressed both in actions (when the director knowingly makes untrue statements to the other party) or in omission (when the director conceals information from the other party, which, when it had been known to the other party, would have resulted in the other party not concluding the contract). ${ }^{31}$

\footnotetext{
${ }^{24}$ Franz Jürgen Säcker and Roland Rixecker, Münchener Kommentar zum Bürgerlichen Gesetzbuch, $5^{\text {th }}$ ed. (München: C.H. Beck, 2009), § 826 at Rn. 38.

${ }^{25}$ When ordering compensation for damage, the creditor's situation must be viewed as if the transaction had not taken place at all (ibid., § 826 at Rn. 51; Felix Steffek, supra note 2, p. 572).

${ }^{26}$ Art 1269 of the Spanish Civil Code.

27 The Judgment of the Provincial Court (SAP) of Palma de Mallorca, supra note 6. Spanish law distinguishes between intentional deceit (dolo grave) and incidental deceit (dolo incidental). In legal practice, incidental deceit has been sometimes set equal to liability on the basis of culpa in contrahendo (SAP Castellón de la Plana 1534/2000, of October 2, 2000). Unlike dolo grave, dolo incidentaldoes not enable annulment of transaction; however, claims for compensation of damage can be filed. See also supra note 67

${ }^{28}$ SAP Madrid 13150/2012, of July 11, 2012; SAP Madrid 2208/2012, of February 20, 2012.

${ }^{29}$ Ibid.

${ }^{30}$ Companies Act (Spain) [Texto Refundido de la Ley de Sociedades de Capital - TRLSC], Official State Bulletin [Boletín Oficial del Estado], BOE-A-2010-10544. Art 241 of TRLSC stipulates the general basis of claim against directors and according to that, shareholders and third parties may claim compensation for damage from directors if they are directly damaged by directors' unlawful activities. Intentional deceitful harming may be one of such unlawful activities.

31 Jesus Alfaro Águila-Real, "La Llamada Acción Individual de Responsabilidad contra los Administradores Sociales" [So called Individual Liability Claim against the Directors of a Company]: 39 // http://www.estig.ipbeja.pt/ ac_direito/individual.pdf (accessed May 12, 2013).
} 
In order to ascertain intent, the offender's will to commit an unlawful deed must be proven. Similarly to German law, the offender's intent does not necessarily have to be aimed at damaging the injured party ${ }^{32}$ and it is not required that the offender has foreseen all possibly harmful consequences of his/her activities. It is enough if it has been established that the offender was aware of the fact that his/her act or omission is unlawful and may cause damage to the injured party. ${ }^{33}$

As in German law, intentional behaviour contrary to good morals forms an independent basis of a tortious claim in Estonian law as well. Article 1045(1)(8) of the LOA provides that the causing of damage is unlawful if, above all, the damage is caused by intentional behaviour contrary to good morals. ${ }^{34}$ The Estonian Supreme Court has repeatedly stated that an act or deed that is in accordance with good morals may become contrary to good morals if the offender's aim to cause damage to the injured party is established. ${ }^{35}$ The judicial practice so far has, however, shown that, as a rule, it is impossible for an injured party to prove the intent of damage. ${ }^{36}$

If the deed is already contrary to good morals in its nature, the injured party does not have to prove that the offender wished to damage the injured party with direct intent similarly to other countries studied in the article. It is enough if the person who intentionally acted contrary to good morals understood or had to understand that his/her actions may cause damage to the injured party and due to that an unlawful consequence occurred. ${ }^{37}$

As in Germany, it is at the discretion of courts to decide in each separate case whether disclosure of untrue statements by a director is contrary to good morals in its nature. But unlike Germany, there is not much legal practice in that matter in Estonia yet and for that reason it is difficult to point out general criteria on the basis of which courts could decide whether defendants' behaviour is contrary to good morals or not in each separate case. The authors are of the opinion that Estonian judicial practice should proceed from the notion that not every exaggeration in disclosure of information is contrary to good morals. Also, disclosure of untrue statements that did not have determinative importance on the injured party from the viewpoint of conclusion of the contract should not be considered contrary to

\footnotetext{
32 SAP Coruña 3002/2012, of December 7, 2012; SAP Coruña 1681/2010, of June 28, 2010.

33 Mariano Yzquierdo Tolsada, Sistema de Responsabilidad Civil, Contractual y Extracontractual [The System of Civil Liability, Contractual and Tortuous] (Madrid: Dykinson, 2001), p. 236.

34 The fact that directors can basically be held liable on the basis of art 1045(1)(8) of the LOA, is, for example, derivable from the Supreme Court's Judgement 3-2-1-7-10, of March 31, 2010.

35 The Supreme Court's Judgement 3-2-1-37-08, of May 8, 2008, and the Supreme Court's Judgement 3-2-1-67-10, of December 21, 2010.

36 The offender's intent to cause damage to the injured party could not be ascertained in either of the judgements referred to in supra note 35 .

37 Paul Varul, et al., supra note 4, p. 651 .
} 
good morals either. ${ }^{38}$ The injured party's own contributory fault should form a basis for decreasing the defendant's liability only if the injured party's intent or gross negligence is proven. ${ }^{39}$ Only deliberate disclosure of false information that was of decisive importance to the injured party during the conclusion of the transaction, meaning that the injured party would not have concluded the transaction at all or would have done it on significantly different terms if he/she had known the correct circumstances, should be considered as contrary to good morals.

As seen above, personal liability of a director for intentional disclosure of untrue statements is possible in each of the countries studied in the article. Common characteristics that form the basis of this liability in all of the countries are intent of the offender and unfair nature of the deed. However, from a legal dogmatic perspective, the countries approach this issue differently. For example, differently from German and Estonian law, English law does not put emphasis on whether the deed was contrary to good morals or not. English courts assess if the fraudulent statement was made with intent that the claimant would rely on it in his action. In Spain courts need to assess the deceitful (doloso) behaviour of the person causing damage. Although there are common elements in the approaches of all the countries referred to in the article, it is difficult to compare English deceit, German/Estonian contrariety to good morals and Spanish dolo grave from the legal dogmatic perspective. However, as a conclusion of the comparison of the countries it is possible to point out criteria that, according to the authors, are significant from the perspective of directors' personal liability and could be used as examples in future judicial practice.

The authors find that liability of directors to third parties should not accompany any kind of disclosure of untrue statements. Directors should not be held liable if they have disclosed false information that has not significantly affected the injured party's decision to conclude a transaction. Also, directors should not be held liable for every kind of exaggeration or glorification of circumstances. It is typical that directors try to avoid telling openly about all aspects of negative circumstances and focus on the positive aspects maybe more than they give rise to. ${ }^{40}$

\footnotetext{
${ }^{38}$ If the disclosure of false information has only insignificant effect on the decision of the injured party or has no effect at all, liability of a director must be denied due to lack of cause-and-effect relationship between the violation and damage.

${ }^{39}$ According to information available to the authors, the issue of injured party's contributory fault has not been handled in false information cases in Estonian courts so far. The general provision (art. 139 of the LOA) that regulates the question of injured party's contributory fault does not rule out the possibility of reducing the defendant's liability in case of injured party's simple negligence; however, the authors find that if the offender has disclosed false information intentionally the injured party's contributory fault may form a basis for decreasing the offender's liability only in case of intentional behaviour or at least gross negligence.

${ }^{40}$ For example, it is widespread that goods (food, hotel rooms, etc.) are made to look much better on photos than they do in reality. Therefore, there are probably many hotel guests who have been
} 
Regarding the question of whether directors should be only held liable for active misrepresentation or also for remaining silent, the authors support the position of German and Spanish courts that directors should be held liable for nondisclosure as well. The authors are of the opinion that not telling important information may influence a creditor's decision regarding a transaction similarly to active misrepresentation. Although one may state that active misrepresentation is somehow a more grave violation than just remaining silent, it may often simply be a question of choosing the right 'sales technique' in order to cause the other party in a contract to make a mistake. ${ }^{41} \mathrm{~A}$ director should not escape liability simply for not actively lying if the other party does make a mistake due to the fact that recognizably important information is deliberately hidden from that party.

The other party's own negligence in verifying information should not provide grounds to discharge the director from liability unless incorrectness of information was clearly obvious, but the creditor still recklessly relied on that information. The authors are of the opinion that within economic circulation a creditor should not have to presume that $\mathrm{s} /$ he is being deceived and, therefore, should not always have to check the statements made by the other contracting party from independent sources. Furthermore, a director has a very simple and inexpensive way to refrain from liability-namely, by disclosing accurate information to the other contracting party.

In conclusion, the authors find that direct liability of a director is justified in circumstances where a director intentionally and significantly influenced an injured party's decision regarding the conclusion of a transaction or important conditions of the transaction by disclosing false information (or by hiding information).

\section{A DIRECTOR'S PERSONAL LIABILITY FOR NEGLIGENT MISREPRESENTATION OR FOR CULPA IN CONTRAHENDO}

As seen from the previous section, if a director has intentionally made untrue statements and through that violated the trust of a third party to a great extent, the third party is entitled to demand compensation for the damage caused by the director. However, it can be presumed that proving the intent of a director may be often quite complicated, which is why the purpose of further analysis is to establish

disappointed when entering their hotel room and thinking back at the beautiful photos they saw previously at the web page or in a tourist brochure. The lastly mentioned does not, however, mean that a fraud has been committed because in perfect light conditions and from the right angle the hotel room probably does look like on the picture.

${ }^{41}$ For example, if a director of a company that sells used cars knows that the odometer reading of a car has been altered, is there a difference whether the director actively lies claiming that the odometer's reading is correct or allows the buyer to look at the reading and does not say anything about the fact that the reading has been altered (i.e., allows the buyer to fall into the trap)? In both cases the buyer would not have bought the vehicle if he/she had known the correct reading. 
if and on what conditions a director can be held liable to third parties for negligent disclosure of untrue statements.

Development of tortious liability for negligent misrepresentation has been hindered by fear of indeterminancy of liability risks. Thus, in the first half of the twentieth century threat of "liability in an indeterminate amount for an indeterminate time to an indeterminate class" was described in the United States' Ultramares case. ${ }^{42}$

In time, case law has developed an important exception, which enables personal tortious liability in case of negligence if the defendant has assumed responsibility for the claimant's economic well-being. ${ }^{43}$ Assumption of responsibility is the result of long-time development of judicial practice, which started with a highly important case in English law, the Hedley Byrne case. ${ }^{44}$ The House of Lords came up with the idea of a "special relationship" in Hedley Byrne. Lord Morris held that:

If in a sphere in which a person is so placed that others could reasonably rely on his judgment or his skill or on his ability to make careful inquiry, a person takes it on himself to give information or advice to, or allows his information or advice to be passed on to another person who, as he knows or should know, will place reliance on it, then a duty of care will arise. ${ }^{45}$

Assumption of responsibility can be verified by considering if an ordinary responsible person in a claimant's position having taken into consideration all circumstances would have believed that the defendant has assumed responsibility. ${ }^{46}$ If the claimant is more skilled or experienced in the matter than the defendant, then relying on the assumption of responsibility is not justified. ${ }^{47}$

In Williams $v$ Natural Life Health Foods ${ }^{48}$ the court did not recognize the plaintiffs' claims against the director. Yet, the case is considered a landmarkdecision for negligent misrepresentation matters. ${ }^{49}$ According to this case, the plaintiffs entered into negotiations with a company to franchise a retail health food shop. In the court they referred to the brochure of the company which marketed the company as having vast experience to operate as a franchisor because of director's personal involvement in the health food business. The House of Lords

\footnotetext{
42 Ultramares Corpn v Touche 174 N E 441, 450 (1931).

43 Andrew Grubb, et al., The Law of Tort (Butterworths LexisNexis, 2002), p. 568.

${ }^{44}$ Hedley Byrne and Co v Heller and Partners [1963], 2 All ER 575 (HL).

${ }^{45}$ See a more thorough analysis on Hedley Byrne: Simon Deakin and Basil Markesinis, Tort Law, $6^{\text {th }}$ ed. (Oxford: Clarendon Press, 2008), p. 160 et seq.

${ }^{46}$ Andrew Grubb, et al., supra note 43, p. 569; W. V. H. Rogers, supra note 12, p. 490.

47 John Hodgson and John Lewthwaite, Tort law, $2^{\text {nd }}$ ed. (Oxford University Press, 2007), p. 93.

${ }^{48}$ Williams v Natural Life Health Foods [1998] 2 All ER 577.

49 See more on the meaning of this case: David Howarth, et al., Hepple, Howarth and Matthews 'Tort: Cases and Materials, $5^{\text {th }}$ ed. (London: Butterworths, 2000), p. 225 and 628; Michael A. Jones, Textbook on Torts, $8^{\text {th }}$ ed. (Oxford University Press, 2002), p. 122-123.
} 
decided that the director of the company could not be held personally liable. For personal liability, he would have had to assume personal responsibility for the advice he had given; however, there had been no personal dealing between the director and the franchisee. It was not a case of simple reliance; it was a question of whether the franchisees could reasonably and objectively have relied on the director's personal assumption of responsibility. ${ }^{50}$

Negligent misrepresentation as a separate tortious basis of claim is not known in the other countries researched here. By analogy it is possible to compare it to director's liability based on culpa in contrahendo (c.i.c.) in German law ${ }^{51}$, which recognizes a clear duty to negotiate with care, and not to lead a negotiating partner to act to his detriment before a firm contract is concluded. ${ }^{52}$

Even if precontractual negotiations do not lead to the conclusion of a contract the negotiations itself create a quasi-contractual reliance between the parties and both parties are under the obligation to inform the other party of circumstances that are essentially and recognizably important to that party when considering the purpose of the contract. This obligation, however, lies on the company pursuant to article 31 of the BGB and activities of the director are considered as activities of the company. 53

In order to file a direct claim against a director based on c.i.c., the director must have a strong personal economic interest in the transaction or there must be a special personal reliance between the director and company's contracting partner. ${ }^{54}$ German judicial practice has been contradictory and uncertain regarding personal economic interest. Although the German Supreme Court ${ }^{55}$ has previously found that personal economic interest is grounded simply on the basis of being one of the shareholders of a company ${ }^{56}$, in later practice it has been found that the fact alone that the director is also a sole shareholder of the company is not enough to hold the director directly liable based on c.i.c. ${ }^{57}$ In its decision of June $6,1994,{ }^{58}$ the $\mathrm{BGH}$ found, differently from earlier judicial practice, that personal economic interest cannot be identified solely on the basis of personal surety or other security

\footnotetext{
50 Peter Loose, Michael Griffiths, and David Impey, supra note 10, p. 387; see also John Hodgson and John Lewthwaite, supra note 47, p. 105-106.

${ }^{51}$ Arts 280 and $311(3)$ of BGB.

52 Michael Hoffmann-Becking, et al., Münchener Handbuch des Gesellschaftsrechts, Aktiengesellschaft [Munich's Handbook of the Company Law, Public Limited Company], Vol. 4, $2^{\text {nd }}$ ed. (München: C.H. Beck, 1999), p. 289.

53 Frank Eckhoff, Die Haftung der Geschäftsleiter gegenüber den Gläubigern der Gesellschaft wegen Insolvenzverschleppung [The Liability of the Director to Creditors for Wrongful Trading] (Baden-Baden: Nomos, 2010), p. 96 et seq.

54 Jan Lüsing, Die Pflichten aus culpa in contrahendo und positiver Vertragsverletzung [The Obligations from culpa in contrahendo and Positive Violation of Contractual Duty] (Baden-Baden: Nomos, 2010), p. 320.

${ }^{55}$ In German: Bundesgerichtshof - BGH.

${ }^{56}$ BGH 19.12.1962, WM 1963 p 160, 161.

${ }^{57}$ BGH 23.10.1985, NJW 1986, p 586, 587.

${ }^{58}$ BGH 6.6.1994, BGHZ 126.
} 
given by the director since economically that kind of security acts as substitution for company's equity capital and there is no reason to treat the person who gave that personal security differently from a shareholder who paid up share capital. Existence of personal economic interest has been found possible if the director is so tightly connected to the object of negotiations that he/she as procurator in rem suam is proceeding with his own personal matter from an economic viewpoint-for example, situations where activities of the director are directed at eliminating claims filed against the director personally or where the director wished to shift the contractual performance for the purpose of personal gain. ${ }^{59}$ However, if the abovementioned case groups have been called into question because the director has some personal economic interest in a transaction concluded in the name of the company, it should not widen the expectations of a contracting partner regarding the circle of responsible persons. ${ }^{60}$

Parallel to the personal economic interest of a director, the director's liability deriving from trust to his person has been developed in German judicial practice. ${ }^{61}$ Similarly to negligent misrepresentation of common law, in an exceptional situation the director may be held personally liable to a third party based on c.i.c. if the director has assumed personal trust to "a special extent" and that has significantly influenced the course of negotiations. It is not enough if the director just takes part in the negotiations personally; some additional guarantee for correctness and completeness of presented information must derive from his/her person. ${ }^{62}$ This can, for example, take place in a situation where the director persuades the other party to conclude a contract based on existing close blood relationships between them. ${ }^{63}$ Simply the existence of long-time business relationships has not been found sufficient for the creation of personal reliance by courts. ${ }^{64}$ An impression in the contracting partner must be created by the director that the director himself/herself is responsible for fulfilment of the contract as required even if the contracting partner does not trust the company or trusts it only a little. ${ }^{65}$

There is no special regulation on precontractual liability in the Spanish CC. It is typical of Spanish tort law that, due to lack of regulation of the $\mathrm{CC}^{66}$, courts are forced to base their judgments on general principles of good faith and neminem

\footnotetext{
${ }^{59}$ Frank Eckhoff, supra note 53, p. 102 et seq.

${ }^{60}$ Ibid., p. 109.

61 Wilhelm Uhlenbruck and Heribert Hirte, supra note 18, p. 312.

62 Marcus Lutter, et al., GmbH-Gesetz, Kommentar, 18 ${ }^{\text {th }}$ ed. (Köln: Verlag Otto Schmidt, 2012$)$, p. 1163.

63 BGH 23.2.1983, BGHZ 87, p 27, 32.

${ }^{64}$ BGH 1.7.1991, WM 1991, p 1548, 1549.

65 Marcus Lutter, et al., supra note 62, p. 1164.

66 The part on tort in Spanish CC includes only nine articles; some of those articles are quite outdated making the scope of application of those few provisions very narrow. E.g., art 1910 of the CC stipulates specifically the liability of the head of household for damage caused from falling of things in the house he lives in. As a comparison, tortious matters in the Estonian Law of Obligations Act, which came into force in 2002, are regulated in 25 articles.
} 
laedere (do not damage no one) when solving different tortious claims and 'stretch ' the scope of application of the general basis of tortious liability of the CC. Thus, the Spanish courts have solved cases of precontractual liability based on the above mentioned general principles and articles 7, 1902 of the CC as well. ${ }^{67}$ For that reason, according to ruling opinion, cases of precontractual liability can be handled as tortious damage. ${ }^{68}$

The above mentioned principles of good faith and neminem laedere are also applicable to companies and their directors. As a rule, only the company as the party to precontractual negotiations is held liable for damage caused to the other party during precontractual negotiations in Spain as well. As an exception, the director may be held directly liable to third parties as well; however, unlike German and English courts, Spanish courts do not seem to find it relevant that there should be special trust or assumption of responsibility between the director and injured party. ${ }^{69}$ In order to enforce a direct claim it is essential to ascertain that the wrongful behavior of a director would have caused damage to the injured party's economical sphere directly and not reflectively (i.e., not through decrease in assets of the company). ${ }^{70}$ According to Spanish judicial practice, the argument of direct damage strengthens the cause-and-effect relationship and enables to avoid interpretations that would make the director jointly liable for company's obligations. ${ }^{71}$ Although causing damage to a party to negotiations through negligent misstatement may, in principle, also be an unlawful act of a director, Spanish courts have been highly cautious in satisfying such claims since the party entering a transaction must bear the usual economic risk and directors cannot act as

67 SAP Madrid 9843/2013, of 07 May 2013. The concept of culpa in contrahendo is familiar to Spanish courts and it has been used in judicial practice quite often in addition to terms "precontractual liability" and "dolo incidentar". See: Spanish Supreme Court 's Judgment (STS) 3068/2013, of May 6, 2013; STS 6635/2011, of October 15, 2011; STS 3067/2009, of May 21, 2009.

68 STS 9982/1988 of May 16, 1988. Gema Tomás Martínez, "Naturaleza de la Responsabilidad Precontractual (Culpa in Contrahendo) en la Armonización Jurídica Europea" [The Nature of Precontractual Liability (culpa in contrahendo) in the European Legal Harmonization], Revista de derecho (Coquimbo) (1/2010) // http://www.scielo.cl/scielo.php?pid=S071897532010000100009\&script=sci_arttext (accessed May 18, 2013); A. Cabanillas Sánchez, "El ámbito de la responsabilidad precontractual o culpa in contrahendo" [The Extent of the Precontractual Liability or culpa in contrahendo], Revista Crítica de Derecho Inmobiliario (1995): 747.

${ }^{69}$ SAP Santander 352/2002, of February 14, 2002; SAP Castellón de la Plana, supra note 27. There are also authors who are of the opinion that liability of directors on the basis of c.i.c. may exist as an exception on similar grounds to German and English law - if the director arouses special trust in the other party towards himself/herself or creates a legitimate impression that he/she assumes personal liability for the fulfilment of the contract (Jesús Alfaro Águila-Real, supra note 31: 44).

70 Art 241 of TRLSC (see note 30). See also: SJM Murcia 142/2011, of October 6, 2011; SAP Salamanca $339 / 2013$, of June 3, 2013. However, personal liability of a director may arise also on the basis on some other specific provisions, like art 172bis of the Bankruptcy Act (Spain) (Official State Bulletin [Boletín Oficial del Estado], BOE-A-2003-13813) if the director has delayed submitting the debtor's bankruptcy petition. In addition, there is a sanctional, guarantee-like liability of directors in Spanish law pursuant to art 367 of the TRLSC for not fulfilling its statutory duties when grounds for termination of the company occur. Both mentioned bases of claims form a separate topic and remain outside the scope of this article. ${ }^{71}$ STS 14024/1992, of May 21, 1992. 
guarantors to company's obligations. ${ }^{72}$ Therefore, simply a negligent misstatement about the economic condition of a company during the conclusion of a transaction may not bring with it the direct liability of a director to the other party on the basis of c.i.c. ${ }^{73}$

In Estonia general principles of precontractual negotiations are stipulated in article 14 of the LOA. ${ }^{74}$ As in Germany, a position has been expressed in Estonian legal literature that a person (director) who evokes reasonable trust towards himself/herself as a potential party to a contract and with that significantly influences another party to a contract in making the decision to enter into the contract may be held liable for violation of precontractual protection obligation. ${ }^{75}$

The possible liability of a director as a representative of a company on the basis of c.i.c. was first covered in Estonian judicial practice in the Supreme Court's judgment of April 30, 2013. ${ }^{76}$ It was possible to conclude from that judicial decision that a director who disclosed untrue statements in the preparatory stages of a transaction could always be held jointly liable with the company on the basis of c.i.c.. However, on June 5, 2013 the Supreme Court made another judgment ${ }^{77}$ in which it specified applicability of c.i.c. based liability of directors and stated a supplementary condition that for the liability to occur, there has to be special trust between the injured party and director or economic interests of the director must coincide with company's economic interests. By adding the trust criterion, the Supreme Court took the same position in applying c.i.c. as German judicial practice. However, the judgment of the Supreme Court does not explain what was meant by overlapping of economic interests. The authors find that it would be advisable to

72 SAP Castellón de la Plana, supra note 27; STS 3067/2009, supra note 67; SAP Pontevedra, of January $31,1994$.

${ }^{73}$ SAP Castellón de la Plana, supra note 27; SAP Navarra, of February 15, 1995.

${ }^{74}$ See more on application of c.i.c. principle in Estonia: Tambet Tampuu, Lepinguvälised võlasuhted [Non-contractual Relations], $3^{\text {rd }}$ ed. (Juura, 2012), p. 159 et seq.; see also: Janno Lahe, "Lepingueelsete kohustuste ning eellepingu rikkumisest tulenev tsiviilõiguslik vastutus" [Liability for Breach of Precontractual Relations], Juridica (10/2004).

75 Paul Varul, et al., supra note 4, p. 64. However, contrary to valid judicial practice in Germany (BGH 23.10 .1985 , NJW 1986, p 586, 587) a position has been presented that liability of a director on the basis of c.i.c. could be presumed in Estonia purely on the reason if the director acts through one-person company or entirely controls the decisions of the company through some other way. See more on that position: Urmas Volens, Usaldusvastutus kui iseseisev vastutussüsteem ja selle avaldusmisvormid, dissertatsioon [Reliance Liability as an Independent Liability Regime and its Types of Expression, Dissertation] (Tartu Ülikooli kirjastus, 2011), p. 285.

76 The Supreme Court's Judgment 3-2-1-39-13, of April 30, 2013. In the referred case a company sold an apartment by hiding from the buyer that the apartment is encumbered by a large financial obligation for the benefit of the apartment association. Although the director was not a defendant in the given case, the Supreme Court, among other things, referred to the possibility that the director (who represented the company during the conclusion of the transaction) could be held jointly liable with the company on the basis of c.i.c.

77 The Supreme Court's Judgment 3-2-1-62-13, of June 5, 2013. In that case a company that sold security devices to another company was not the owner of the devices. The purchase agreement was financed through leasing and the lessor was to become the owner of that equipment. However, as the seller was unable to transfer the right of ownership, the lessor never became the owner of the equipment. The lessor filed a claim against the director of the seller on the basis that the director hid the fact that the equipment did not really belong to the seller. 
proceed from German judicial practice, according to which overlapping of economic interests should not result in personal liability of directors on the basis of c.i.c.

Despite the fact that c.i.c. as a dogmatic legal concept is alien to English law, negligent misrepresentation is a type of conduct which illustrates the operation of the c.i.c. principle. ${ }^{78}$ Similarly to c.i.c. liability, the basis of negligent misrepresentation liability is the formation of a special reliance between the director and injured party and assumption of responsibility by the director, which is why treatment of c.i.c. known in German and Estonian law can be considered to be substantially close to negligent misrepresentation familiar to English law. Although in Spanish law there is no separate legal basis that would enable liability on the basis of c.i.c., this legal institute is well known in Spanish judicial practice as well.

The authors support the position presented in German law (and similarly in English law) that the liability of directors as representatives on the basis of c.i.c. should be extremely exceptional and should primarily be based on the creation of special reliance between the director and the third party. ${ }^{79}$ Through such an approach it is possible to keep directors' liability for c.i.c. (or for negligent misstatements) in tight and well-defined frames. Although liability of directors on the basis of c.i.c. is exceptional in Spanish judicial practice as well, the authors find it cannot be determined clearly enough. The authors are of the opinion that the 'stronger' cause-and-effect relationship mentioned in Spanish judicial practice is difficult to measure. ${ }^{80}$

Unlike the Supreme Court of Estonia, the authors find that taking into consideration personal economic interests of directors when determining their c.i.c. liability is not advisable. To a larger or smaller extent directors are always personally interested in the economic state of their companies. ${ }^{81}$ According to the opinion of the authors, taking into consideration directors' economic interests would raise questions about directors' free entrepreneurship, i.e., freedom to decide to which extent they would like to be tied to the company. Free entrepreneurship is one of the main preconditions of economic growth and restricting it may have a much more harmful effect on the society than the gain creditors may receive from stricter personal liability of directors. There is also no reason to fear that obvious cases of corporate abuse would remain uncovered; it should be possible to solve

\footnotetext{
${ }^{78}$ Friedrich Kessler and Edith Fine, "Culpa in Contrahendo, bargaining in Good Faith, and Freedom of Contract: a Comparative Study," Harvard Law Review (1964): 437.

${ }^{79}$ Of course other preconditions for compensation of damage, such as unlawfulness and wrongfulness of violation, causing damage to the injured party and existence of cause-and-effect relationship between the violation and damage, must exist as well.

${ }^{80}$ Ascertainment of cause-and-effect relationship is an unavoidable precondition for enforcing a claim for damage in other countries studied in the article as well.

${ }^{81}$ If a director is also a shareholder, his/her dividend income may depend on it; however, even if the director is merely a paid employee, his/her income (e.g., annual bonus) will still depend on how well the company is doing.
} 
those cases on the tortious basis explained in the previous section of this article (i.e intentional misrepresentation).

\section{DIRECTOR'S PROSPECTUS LIABILITY}

In individual cases liability of a director for making untrue statements may also proceed from a statutory provision. That liability can come into question together with director's liability for c.i.c. or deceit, but it may also be an additional basis of liability. Above all, the purpose of those provisions is to protect a third party for damage arising from violation of obligation stipulated in the provision. As liability for breach of statutory duties can often occur in conjunction with negligence, it will significantly reduce the plaintiff's burden of proof in comparison to a situation where the plaintiff is required to prove intent of the tortfeasor.

Next, we will analyze a protection provision that is important from the viewpoint of directors' liability for misrepresentation and that has been transferred into the law of the EU member states on the basis of article 6 of the European Prospectus Directive ${ }^{82}$.

In England ${ }^{83}$ the Financial Services and Markets Act 2000 (FSMA) imposes personal liability to third parties on directors. The FSMA, s 90 imposes personal liability on directors for untrue or misleading statements in prospectus and listing particulars. Similar liability was provided already in the Director's Liability Act 1890 as reaction to the decision in Derry $v$ Peek $^{84}$, where the House of Lords did not agree with the extension of director's liability to negligent statements. ${ }^{85}$ The Act 1890 established liability of a director for misstatements in a prospectus also for negligence. ${ }^{86}$ Hence this statute helps to fill a gap in the case law, which would otherwise significantly inhibit filing prospectus liability claims against directors in cases where director's deceit is missing.

82 Directive 2003/71/EC of the European Parliament and of the Council of 4 November 2003 on the prospectus to be published when securities are offered to the public or admitted to trading and amending Directive 2001/34/EC, OJ L 345, 31.12.2003, p. 64. In addition to prospectus liability there are of course other protection provisions; yet, it is not possible to present a comprehensive directory of all protection provisions as judicial practice is constantly changing, and for that reason the authors will not cover other protection provisions in the article.

${ }^{83}$ In England the breach of statutory duty is an independent tort. Law may provide civil liability for violation of a specific duty; however, liability for statutory duty may also proceed from protection purpose and from a more general meaning of law (Mark Lunney and Ken Oliphant, Tort Law, $2^{\text {nd }}$ ed. (Oxford University Press, 2003), p. 561 et seq.).

${ }^{84}$ Derry $v$ Peek (1889), 14 App Cas 337. See more about the decision in Derry $v$ Peek: Anthony M. Dugdale, Michael A. Jones et al., Clerk \& Lindsell on Torts, $19^{\text {th }}$ ed. (London: Sweet \& Maxwell, 2006), p. 1089 et seq.

85 Lexa Hilliard, "Liabilities of Directors to Third Parties": 834 et seq.; in: Simon Mortimore QC, ed., Company directors, duties, liabilities, and remedies (Oxford University Press, 2009).

${ }^{86}$ R. F. V. Heuston and R. A. Buckley, supra note 15, p. 376. 
Similarly to director's liability under English FSMA, in Germany ${ }^{87}$ a director may be held liable for disclosing false information in a prospectus of a public limited company that is a primary market player pursuant to articles 21-25 of the German Securities Prospectus Act. ${ }^{88}$ However, the director's liability under the German Securities Act is more restrictive and the director cannot be held liable solely on the basis of his/her position as a director, but he/she must also have some kind of personal interest in the issue of securities. For example, it is enough if the director is interested in transferring his/her own shareholding after the issue of securities. ${ }^{89}$

In addition, prospectus liability on the basis of the above-mentioned culpa in contrahendo has been found possible in the $\mathrm{BGH}$. When acquiring securities on the basis of prospectus then usually the prospectus is the most important source document for making investment decisions, which is why the creators of prospectuses attain a special reliance status. Differently from the usual c.i.c. liability situation, a special reliance status does not have to take place between a director and a third party, instead it is proceeded from a so called typified reliance, i.e., the investor is not required to even be personally acquainted with the director; in order for liability to come about, it is enough if the director is part of the group of people responsible for the prospectus. ${ }^{90}$

According to an alternative opinion, Prof. Helmut Koziol has found that in the case of prospectus liability, there is no direct contact between injured parties and people responsible for the prospectus, which is why prospectus liability cannot be grounded by improvements to c.i.c. principle. However, similarly to the position of the $\mathrm{BGH}$, Prof. Koziol also agrees that data presented in the prospectus makes investors feel special trust and thus, liability of people responsible for the prospectus must be affirmed if that trust is violated. ${ }^{91}$

Pursuant to article 28 of the Spanish Financial Markets Act ${ }^{92}$, a director is held liable for compensation of damage that has been caused to an investor through disclosure of false information in a prospectus or by leaving out important

\footnotetext{
${ }^{87}$ In German law enforcing different tortious claims has been made easier by 'transmission provision ' in art $823(2)$ of the BGB, which widens the scope of application of tortious liability to all provisions which protect third parties and where the circle of protected persons is sufficiently determined. See more on the nature of protection provision: Maria Cristina Ciota, supra note 22, p. 138 et seq.

${ }^{88}$ In German: Wertpapierprospektgesetz (WpPG), Federal Law Gazette (BGBI), I p. 1698. Until October 31,2007 , regulated on the basis of arts 44-47 of BörsG.

${ }^{89}$ Daniel Möritz, Haftung des Managements und Drittschutz [The Liability of the Management and the Protection of third Persons] (Baden-Baden: Nomos, 2011), p. 103-104; see also: Eva-Maria Wild, Prospekthaftung einer Aktiengesellschaft unter deutschem und europäischem Kapitalschutz [Prospectus Liability of a Public Limited Company according to the German and European Capital Protection Rules], (Köln: Carl Heymanns Verlag, 2007), p. 83-84.

90 BGH 6.10.1980, BGHZ 79, 337; Rocco Jula, Der GmbH-Geschäftsführer [The Director of a GmbH], $4^{\text {th }}$ ed. (Springer, 2012), p. 290.

91 Helmut Koziol, Grundfragen des Schadenersatzrechts [General Questions of the Tort Law] (Jan Sramek Verlag 2010), p. 98.

92 Financial Markets Act (Spain) (in Spanish: Ley del Mercado de Valores), Official State Bulletin [Boletín Oficial del Estado], BOE-A-1988-18764.
} 
information..$^{93}$ Unlike the German Securities Prospectus Act, Spanish law does not require that there should be some sort of a special interest towards emission for the director to be held personally liable.

Unlike other countries under research, the securities market regulation valid in Estonia does not enable personal prospectus liability of a director. Article 25 of the Estonian Securities Markets Act ${ }^{94}$ limits the liability for disclosing false or incomplete data in the prospectus only to the issuer and offeror. Although the previously mentioned provision also acts as a protection provision, it does not stipulate personal liability of directors and, therefore, it cannot be implemented as a basis for claims filed against directors. ${ }^{95}$ However, this gap could be overcome similarly to German judicial practice through recognition of prospectus liability of a director on the basis of c.i.c. ${ }^{96}$ As noted above, the Supreme Court of Estonia ${ }^{97}$ has already recognized the possibility of directors' liability on the basis of c.i.c. Although issues related to prospectus liability of directors have not yet been solved in Estonian judicial practice, the authors do not see any reason why Estonian courts could not recognize directors' prospectus liability on the basis of c.i.c. by supporting it with the so called typified trust. Otherwise investors could file claims against directors who disclose false information in prospectuses only on the basis of intentional behavior contrary to good morals.

Despite the fact that prospectus liability of directors is similarly based on article 6 of the European Prospectus Directive in each of the countries analyzed in the article, the issue of directors' liability is nationally solved differently. When in England and Spain a director is fully liable for damage caused by disclosing false information in a prospectus, in Germany directors' liability is restricted to those cases where a director also has some sort of personal interest in the emission. The Estonian Securities Markets Act, however, does not stipulate any kind of personal liability of directors for disclosure of false information.

Although article 6 of the European Prospectus Directive gives a certain freedom of choice for the member states in stipulating liability, the authors are of the opinion that prospectus liability of directors should be more consonant among member states. For example, a British investor may get confused when he/she

\footnotetext{
${ }^{93}$ A director may be held personally liable to investors for presenting untrue statements in a prospectus on the basis of the art 28 of the Spanish Financial Markets Act and art 241 of the TRLSC. In Spain it is possible to hold a director liable to third parties on the general basis of art 241 of the TRLSC if damage is caused through violation of some other legal provision. The director will not be held liable for violation of any kind of legal provision, but only in situations where the director can be personally reproached for violation during execution of his/her activities. This can mostly happen in situations where the director was able and had to prevent, avoid or reduce the damage caused to a third party (Guillermo Guerra Martín, et al., La responsabilidad de los administradores de sociedades de capital [The Liability of the Directors of a Company] (Madrid: Wolters Kluwer España, La Ley, 2011), p. 213-214).

94 Securities Markets Act (Estonia), State Gazette, (Riigi Teataja), part 1, December 23, 2013, No. 33.

${ }_{95}$ However, this provision does stipulate the liability of the issuer and offeror.

96 See supra note 90.

97 See supra note 77.
} 
unexpectedly finds out that a director of an Estonian issuer is not personally liable for disclosure of false information in the prospectus. Therefore, it would be advisable to alter the European Prospectus Directive and through that also the national legislation so that the issue of directors' prospectus liability would be solved principally in a same way in all member states.

The authors find that personal liability of directors for disclosure of false information in a prospectus should not be precluded. Information contained in prospectuses has determinative importance for investors when making investment decisions and when looking at the bigger picture, and the functioning of securities market as a whole is dependent on investors' trust for information presented in prospectuses. When investors have little trust in the information contained in prospectuses, it is less likely that companies will raise new capital and that in turn will have a negative influence on business activity in society as a whole. For that reason the authors are in favor of full liability of directors for compensating damage caused by disclosing false information in prospectuses. According to the authors, the restriction which is stipulated in the German Securities Prospectus Act and states that a director must have personal interest in emission for him/her to be held liable is not advisable. The authors find that the purpose of the regulation should be protection of investors and the personal interests of directors should be irrelevant at this point.

\section{CONCLUSIONS}

Tortious bases of liability for deceit and negligent misrepresentation known in the common law system are alien to the legal systems of the countries studied in this article; however, that does not mean that directors are not held liable in those countries for disclosure of false information. It has been found through analysis that tortious claims that are filed in England on the basis of deceit can be similarly filed as tortious claims in Germany, Spain and Estonia as well by reasoning the claims with intentional behavior contrary to good morals or with dolo grave. The principle of culpa in contrahendo corresponds best to negligent misrepresentation and in many cases it allows the courts to reach similar outcomes when solving cases. In addition, the liability of a director may arise when a specific protection provision is violated, as was analyzed under prospectus liability.

All in all it can be said that directors cannot be held personally liable to creditors for any kind of disclosure of false information. When untrue statements are intentionally disclosed, directors are not liable for every kind of exaggeration and glorification of situations, but false information has to have a significant 
meaning when considering the object and purpose of the contract and it must have a determinative influence on the decisions of the other party (whether to conclude the contract and on which terms). Directors are not liable in situations where no damage has been caused through disclosure of false information. The injured party should not have to presume the other party's deceit and failure to check the offender's statements should not restrict the offender's liability unless the injured party himself/herself expressed intent or gross negligence. The authors find that restricting directors' liability merely to active misrepresentation is not advisable and directors should be held personally liable also for hiding important information for which the other party had a clearly recognizable interest.

C.i.c. liability can extend to a director as a representative of a party only in exceptional cases. The authors are of the opinion that affirming c.i.c. liability is advisable only in situations where a director practically discards the role of a representative, assumes the special role of a guarantor and creates special trust in the other party. Taking into consideration personal economic interests of a director is not justified at this point as it calls into question the issue of limiting free entrepreneurship of a director if solely his/her personal participation in economic activities of a company (e.g., as a shareholder) can bring about the director's liability on the basis of c.i.c.

The authors find that prospectus liability of directors should be more consonant in the countries studied in the article, since the securities market acts across borders and directors' prospectus liability regulation at the EU level should not come as a surprise to an investor from another member state. In cases of public emission it is advisable to hold directors more strictly personally liable as it will make the securities market as a whole more reliable to investors. Directors, however, should be able to limit their liability to a reasonable extent by involving enough competent specialists in the process of drafting prospectuses.

\section{BIBLIOGRAPHY}

1. Águila-Real, Jesús Alfaro. "La Llamada Acción Individual de Responsabilidad contra los Administradores Sociales" [So Called Individual Liability Claim against the Directors of a Company] //

http://www.estig.ipbeja.pt/ ac_direito/individual.pdf (accessed May 12, 2013).

2. Bamberger, Heinz Georg, and Roth, Herbert. Beck'scher Online-Kommentar BGB. $27^{\text {th }}$ ed. München: C.H.Beck, 2013. 
3. Cabanillas Sánchez, A. "El ámbito de la responsabilidad precontractual o culpa in contrahendo [The Extent of the Precontractual Liability or culpa in contrahendo]. Revista Crítica de Derecho Inmobiliario (1995): 747-788.

4. Ciota, Maria Cristina. Die deliktische Aussenhaftung des Vorstandes einer Aktiengesellschaft [Tortious Liability of the Management Board of a Public Limited Company]. Aachen: Shaker Verlag, 2008.

5. Deakin, Simon, and Basil Markesinis. Tort Law. $6^{\text {th }}$ ed. Oxford: Clarendon Press, 2008.

6. Deakin, Simon, Angus Johnston, and Basil Markesinis. Markesinis and Deakin 's Tort Law. 5 $5^{\text {th }}$ ed. New York: Oxford, 2003.

7. Dugdale, Anthony, et al. Clerk \& Lindsell on Torts. $19^{\text {th }}$ ed. London: Sweet \& Maxwell, 2006.

8. Eckhoff, Frank. Die Haftung der Geschäftsleiter gegenüber den Gläubigern der Gesellschaft wegen Insolvenzverschleppung [The Liability of the Director to Creditors for Wrongful Trading]. Baden-Baden: Nomos, 2010.

9. Grubb, Andrew, et al. The Law of Tort. Butterworths LexisNexis, 2002.

10. Guerra Martín, Guillermo, et al. La responsabilidad de los administradores de sociedades de capital [The Liability of the Directors of a Company]. Madrid: Wolters Kluwer España, La Ley 2011.

11. Heuston, R. F. V, and R. A. Buckley. Salmond and Heuston on the Law of Torts. $21^{\text {st }}$ ed. London: Sweet\&Maxwell, 1996.

12. Hilliard, Lexa. "Liabilities of Directors to Third Parties": 819-844. In: Simon Mortimore QC, ed. Company directors, duties, liabilities, and remedies. Oxford University Press, 2009.

13. Hodgson, John, and John Lewthwaite. Tort law. $2^{\text {nd }}$ ed. Oxford University Press, 2007.

14. Hoffmann-Becking, Michael, et al. Münchener Handbuch des Gesellschaftsrechts, Aktiengesellschaft [Munich's Handbook of the Company Law, Public Limited Company]. Vol. 4. $2^{\text {nd }}$ ed. München: C.H. Beck, 1999.

15. Howarth, David, et al. Hepple, Howarth and Matthews'Tort: Cases and Materials. $5^{\text {th }}$ ed. London: Butterworths, 2000.

16. Jones, Michael. Textbook on Torts. $8^{\text {th }}$ ed. Oxford University Press, 2002.

17. Jula, Rocco. Der GmbH-Geschäftsführer [The Director of a GmbH]. $4^{\text {th }}$ ed. Springer, 2012.

18. Kessler, Friedrich, and Edith Fine. "Culpa in Contrahendo, bargaining in Good Faith, and Freedom of Contract: a Comparative Study." Harvard Law Review (1964): 401-449. 
19. Koziol, Helmut. Grundfragen des Schadenersatzrechts [General Questions of the Tort Law]. Jan Sramek Verlag, 2010.

20. Lahe, Janno. "Lepingueelsete kohustuste ning eellepingu rikkumisest tulenev tsiviilõiguslik vastutus" [Liability for Breach of Pre-contractual Relations]. Juridica (10/2004): 681-687.

21. Loose, Peter, Michael Griffiths, and David Impey. The Company Director: Powers, Duties and Liabilities. $11^{\text {th }}$ ed. Jordans, 2011.

22. Lunney, Mark, and Ken Oliphant. Tort Law. $2^{\text {nd }}$ ed. Oxford University Press, 2003.

23. Lüsing, Jan. Die Pflichten aus culpa in contrahendo und positiver Vertragsverletzung [The Obligations from culpa in contrahendo and Positive Violation of Contractual Duty]. Baden-Baden: Nomos, 2010.

24. Lutter, Marcus, et al. GmbH-Gesetz, Kommentar. $18^{\text {th }}$ ed. Köln: Verlag Otto Schmidt, 2012.

25. Martínez, Gema Tomás. "Naturaleza de la Responsabilidad Precontractual (Culpa in Contrahendo) en la Armonización Jurídica Europea" [The Nature of Precontractual Liability (culpa in contrahendo) in the European Legal Harmonization]. Revista de derecho (Coquimbo) (1/2010): 187 - 210 // http://www.scielo.cl/scielo.php?pid=S071897532010000100009\&script=sci_arttext (accessed May 18, 2013).

26. Michalski, Lutz, et al. Kommentar zum Gesetz betreffend die Gesellschaften mit beschränkter Haftung (GmbH-Gesetz) [Commentary of the GmbH Act]. Vol. 2. München: C. H. Beck, 2002.

27. Möritz, Daniel. Haftung des Managements und Drittschutz [The Liability of the Management and the Protection of third Persons]. Baden-Baden: Nomos, 2011.

28. Rebmann, Kurt, Franz Jürgen Säcker, and Roland Rixecker. Münchener Kommentar zum Bürgerlichen Gesetzbuch, Schuldrecht, Besonderer Teil III [Commetary of the Civil Code, Civil Law, Special Part III]. Vol. 5. $4^{\text {th }}$ ed. München: C. H. Beck, 2004.

29. Rogers, W. V. H. Winfield \& Jolowicz on Tort. $17^{\text {th }}$ ed. London: Sweet\&Maxwell, 2006.

30. Säcker, Franz Jürgen, and Roland Rixecker. Münchener Kommentar zum Bürgerlichen Gesetzbuch. $5^{\text {th }}$ ed. München: C.H. Beck, 2009.

31. Säcker, Franz Jürgen, Roland Rixecker. Münchener Kommentar zum Bürgerlichen Gesetzbuch. $6^{\text {th }}$ ed. München: C.H. Beck, 2012.

32. Steffek, Felix. Gläubigerschutz in der Kapitalgesellschaft [Creditors Protection in a Company]. Tübingen: Mohr Siebeck, 2011. 
33. Tampuu, Tambet. Lepinguvälised võlasuhted [Non-contractual Relations]. $3^{\text {rd }}$ ed. Juura, 2012.

34. Uhlenbruck, Wilhelm, and Heribert Hirte. Insolvenzordnung, Kommentar [Commantary of the Insolvency Act]. $13^{\text {th }}$ ed. München: Verlag Franz Vahlen, 2010.

35. Varul, Paul, et al. Võlaõigusseadus I, Kommenteeritud väljaanne [Law of Obligations Act I, Commented Edition]. Tallinn: Juura, 2006.

36. Volens, Urmas. Usaldusvastutus kui iseseisev vastutussüsteem ja selle avaldusmisvormid, dissertatsioon [Reliance Liability as an Independent Liability Regime and its Types of Expression, Dissertation]. Tartu Ülikooli kirjastus, 2011.

37. Wild, Eva-Maria. Prospekthaftung einer Aktiengesellschaft unter deutschem und europäischem Kapitalschutz [Prospectus Liability of a Public Limited Company according to the German and European Capital Protection Rules]. Köln: Carl Heymanns Verlag, 2007.

38. Yzquierdo Tolsada, Mariano. Sistema de Responsabilidad Civil, Contractual y Extracontractual [The System of Civil Liability, Contractual and Tortuous]. Madrid: Dykinson, 2001.

\section{LEGAL REFERENCES}

1. Bankruptcy Act (Spain). Official State Bulletin [Boletín Oficial del Estado], BOE-A-2003-13813.

2. BGH (German Supreme Court's Judgment [Bundesgerichtshof]) 1.7.1991, WM 1991, p 1548, 1549.

3. BGH 19.12.1962, WM 1963 p 160, 161.

4. $\quad B G H$ 23.10.1985, NJW 1986, p 586, 587.

5. BGH 23.2.1983, BGHZ 87, p 27, 32.

6. $\quad B G H$ 6.6.1994, BGHZ 126.

7. $B G H 6.10 .1980, B G H Z 79,337$.

8. BGH NJW-RR 1992, 1061.

9. Car and Universal Finance Co Ltd v Caldwell [1965], 1 QB 525.

10. Civil Code (Germany). Federal Law Gazette [Bundesgesetzblatt, BGB/], I p. 42, 2909, 2003 I p. 738.

11. Civil Code (Spain). Official State Bulletin [Boletín Oficial del Estado, BOE], BOE-A-1889-4763.

12. Companies Act (Spain). Official State Bulletin [Boletín Oficial del Estado], BOE-A-2010-10544. 
13. Derry v Peek (1889). 14 App Cas 337.

14. Directive 2003/71/EC of the European Parliament and of the Council of 4 November 2003 on the prospectus to be published when securities are offered to the public or admitted to trading and amending Directive 2001/34/EC. OJ L 345, 31.12.2003, p. 64.

15. Financial Markets Act (Spain). Official State Bulletin [Boletín Oficial del Estado], BOE-A-1988-18764.

16. General Part of the Civil Code (Estonia). State Gazette [Riigi Teataja], part 1, December 6, 2010, No. 12.

17. Hedley Byrne and Co v Heller and Partners [1963]. 2 All ER 575 (HL).

18. Insolvency Act (England). 1986, c. 45 // http://www.legislation.gov.uk/ukpga/1986/45/contents.

19. Law of Obligations Act (Estonia). State Gazette [Riigi Teataja], part 1, November 29, 2013, No. 4.

20. SAP (The Judgment of the Provincial Court [Sentencia de la Audiencia Provincial]) Castellón de la Plana 1534/2000, of October 2, 2000.

21. SAP Coruña 1681/2010, of June 28, 2010.

22. SAP Coruña 3002/2012, of December 7, 2012.

23. SAP Madrid 13150/2012, of July 11, 2012.

24. SAP Madrid 2208/2012, of February 20, 2012.

25. SAP Madrid 9843/2013, of May 7, 2013.

26. SAP Navarra, of February 15, 1995.

27. SAP Palma de Mallorca 1095/2013, of June 4, 2013.

28. SAP Pontevedra, of January 31, 1994.

29. SAP Salamanca 339/2013, of June 3, 2013.

30. SAP Santander 352/2002, of February 14, 2002.

31. Securities Markets Act (Estonia). State Gazette, (Riigi Teataja), part 1, December 23, 2013, No. 33.

32. Securities Prospectus Act (Germany). Federal Law Gazette (BGBI), I p. 1698.

33. SJM (Judgment of the Commercial Court [Sentencia del Juzgado de 10 Mercantil]) Murcia 142/2011, of October 6, 2011.

34. Standard Chartered Bank v Pakistan National Shipping Corporation [2002] UKHL 43, [2003] 1 All ER 173.

35. STS (Spanish Supreme Court`s Judgment [Sentencia del Tribunal Supremo]) 14024/1992, of May 21, 1992.

36. STS 3067/2009, of May 21, 2009.

37. STS 3068/2013, of May 6, 2013.

38. STS 6635/2011, of October 15, 2011. 
39. STS 9982/1988, of May 16, 1988.

40. The Supreme Court's Judgment 3-2-1-37-08, of May 8, 2008 (Estonia).

41. The Supreme Court's Judgment 3-2-1-39-13, of April 30, 2013 (Estonia).

42. The Supreme Court's Judgment 3-2-1-62-13, of June 5, 2013 (Estonia).

43. The Supreme Court's Judgment 3-2-1-67-10, of December 21, 2010 (Estonia).

44. The Supreme Court's Judgment 3-2-1-7-10, of March 31, 2010 (Estonia).

45. Ultramares Corpn $v$ Touche 174 N E 441, 450 (1931).

46. Williams $v$ Natural Life Health Foods [1998] 2 All ER 577. 